\title{
The analysis of barriers for implementing circular economy practices using the Analytic Hierarchy Process (AHP)
}

Hugo Henrique dos Santos ${ }^{1}$, São Paulo State University, Bauru, São Paulo, Brazil

Vitor Natã Marques², Unifafibe University Center, Bebedouro, São Paulo, Brazil

Luiz Felipe Ferreira Paschoali ${ }^{3}$, Unifafibe University Center, Bebedouro, São Paulo, Brazil

\section{RESUMO}

Objetivo - Este artigo tem como objetivo identificar e classificar as principais barreiras para adoção de práticas de economia circular com a aplicação do método Analytic Hierarchy Process (AHP) para priorização. A metodologia proposta avalia a importância de diferentes categorias de barreiras à adoção de práticas de economia circular em empresas do setor alimentício e metalúrgico.

Arcabouço Teórico - Este estudo se fundamentou na teoria vigente de barreiras à adoção de práticas de economia circular e métodos de tomada de decisão com múltiplos critérios.

Metodologia - O método Analytic Hierarchy Process (AHP) foi utilizado para avaliar e priorizar barreiras à adoção das práticas de economia circular. A estabilidade do ranking foi testada com a utilização de análise de sensibilidade.

Resultados - Os resultados indicam diferenças significativas nas classificações de barreiras. Enquanto a empresa do setor alimentício indica que as principais barreiras estão relacionadas com informações técnicas, a empresa do setor metalúrgico considera que as barreiras relacionadas com questões financeiras e econômicas tem um maior impacto.

Contribuições - $\mathrm{O}$ estudo contribuiu no fornecimento de insights para que gestores tenham uma maior percepção das principais dificuldades na adoção de práticas de economia circular, além disso, o estudo contribui para ampliar o escopo de extensão da aplicação de métodos multicritérios em economia circular e avaliar a importância relativa das barreiras.

Palavras-Chave - Economia Circular; Analytic Hierarchy Process; Análise multicritério; Barreiras; Desenvolvimento Sustentável.

\section{ABSTRACT}

Purpose - This paper aims to identify and classify the main barriers for adopting circular economy practices using the Analytic Hierarchy Process (AHP) method for prioritization. The proposed methodology evaluates the importance of different classes of barriers for adopting circular economy practices in a food company and metalworking company.

Theoretical framework - This study was based on the current theory of barriers to adopt circular economy practices and multicriteria decision-making.

Design/methodology/approach - The Analytic Hierarchy Process (AHP) method was used to assess and prioritize barriers for circular economy practices. Stability was ranked using a sensitivity analysis.

Findings - The results indicate significant differences in the classification of barriers. While the food manufacturing company indicate that the main barriers are related to technical information, the metalworking company considered that barriers relating to financial and economic issues have more of an impact.

Originality/value - The study contributes to providing insights so that managers have a greater perception of the main difficulties in adopting circular economy practices, in addition, the study also contributes to extending the application of multicriteria decision making methodologies to the circular economy and evaluating the relative importance of the barriers.

Keywords - Circular Economy; Analytic Hierarchy Process; multicriteria analysis; barriers; sustainable development.

1Av. Engenheiro Luiz Edmundo Carrijo Coube, 14-01. PO BOX 17033-360, Bauru, São Paulo, Brazil, hugo.santos@unesp.br, https://orcid.org/0000-0003-1366-3615;2. vi_nm@ hotmail.com, https://orcid.org/00000001-7497-8309; 3. paschoali95@gmail.com, https://orcid.org/0000-0003-2945-2820.

SANTOS, H.H.; MARQUES, V.N.; PASCHOALI, L.F.F. The analysis of barriers for implementing circular economy practices using the Analytic Hierarchy Process (AHP). GEPROS. Gestão da Produção, Operações e Sistemas, v.16, ${ }^{\circ}$ 3, p. $99-118,2021$. 


\section{INTRODUCTION}

Since the advent of the Industrial Revolution, product manufacturing processes have adopted a linear production model, with an abundant and unconscious use of natural resources, causing a large amount of solid waste that is not reused in new production cycles (LEITÃO, 2015). However, the current scenario requires greater concern with the use of production resources, driven mainly by new projections and new guidelines, such as, for example, the Sustainable Development Goals established by the United Nations that seeks a series of targets. With this in mind, Goal 9 can be mentioned, which highlights the need to promote inclusive and sustainable industrialization, upgrade infrastructure and rehabilitate industries to make them sustainable and improve the technological capabilities of manufacturing sectors (UN, 2015).

Therefore, a new approach to the economic development and operation of companies that allocates environmental economic importance to the center of concerns is essential (LEITÃO, 2015). All economies face a scarcity of raw materials and significant environmental problems (SINTRA, 2019). As such, replacing the linear economy, which is based on extracting, producing, consuming and disposing of waste, with the Circular Economy model, which reallocates waste with the capacity to develop new products or raw materials in the production process, becomes a fundamental task for achieving sustainable development (SINTRA, 2019).

It appears that there are a large number of barriers that, in most cases, are connected to each other and clearly illustrate the complexity of the Circular Economy (WESTBLOM, 2015). While there are different interpretations of the Circular Economy, there is a consensus to close the loop. However, there are countless ways to close the cycle: rethink, reduce, reuse, repair, reform, redefine, recycle and recover energy (KIRCHHERR et al., 2017).

Changing the production model to a circular economy requires activities such as distribution planning, inventory management, production planning and logistics network management, requiring financial innovations, which go along with a substantial amount of time and investment by the company (MATHEWS; TAN, 2011). The lack of capital has been mentioned in the literature as one of the most difficult barriers to be broken to adopt the Circular Economy (RIZOS et al., 2016). Likewise, studies suggest that problems in financing 
synergistic partnerships between two or more companies or restrictive market conditions are considered financial barriers (BUREN et al., 2016).

According to the National Confederation of Industry (CNI), the adoption of circular economy practices brings new challenges to organizations, with an emphasis on innovation in the development of new products adapted to circular practices, reduction of losses in production and logistical processes and the creation of new distribution channels, encouraging reverse logistics and recycling processes. Other challenges mentioned by CNI are the financial investment for new practices and the reformulation of education and innovations, with specialized professionals to deal with this new advent (CNI, 2019). Research on the topic of circular economy and knowledge of the barriers that interfere in the adoption of such practices are still incipient. In addition, investigations to identify similar and different barriers that companies face is an active field of research (GRAFSTROM; AASMA, 2021).

Initially, companies will have to invest capital to transform their businesses, but at a later stage, they will be able to reduce operating costs through more efficient processes that are geared towards the reuse of waste and the use of recycled goods (CNI, 2019).

Considering the Brazilian backdrop and the difficulties that arise in organizations to deal with the new practices of a circular economy, the task of surveying and prioritizing these difficulties becomes an opportunity for relevant research. This enables and accelerates the process of adopting circular economy practices in companies, where decision support tools are needed (LIEDER; RASHID, 2016). To develop this research, a multicriteria method will be used allowing the main barriers to be identified and prioritized for the implementation of Circular Economy practices in companies in different segments using the Analytic Hierarchy Process.

The AHP method is one of the most used methods in the literature for prioritizing barriers. The basic characteristics of AHP are mathematical simplicity, the flexibility to work with complex problems and a structure that can be adapted to any type of problem in which there are variables that must be prioritized (VAIDYA; KUMAR, 2006; SIPAHI; TIMOR, 2010). This method has wide applicability, mainly in studies to prioritize barriers involving sustainable operations practices in organizations and supply chains (PRAKASH; BARUA, 2016; MANGLA; GOVINDAN, LUTHRA, 2017; BHANDARI; SINGH; CARG, 2019). In addition to AHP, several other multi-criteria decision support methods are found in the literature, such as the Analytic Network Process (ANP), the Technique for Order Preference 
by Similarity to Ideal Solution (TOPSIS), among others. However, AHP is the most preferred model compared to other methods since it is easy to use and because of its greater acceptance in the literature (HARPUTLUGIL et al., 2011).

Based on the context shown regarding the circular economy, as well as its implementation difficulties, a question is posed for the research: what are the main barriers to the adoption of circular economy practices? Therefore, this study aims to identify and classify the main barriers to adopting circular economy practices, using the Analytic Hierarchy Process (AHP) method for prioritization. For this purpose, studies were conducted in a food manufacturing company and in a metalworking company.

This research is justified by the benefits that the circular economy adds to a company's sustainable development. By using it, costs, waste, and reusable resources can be reduced. According to research carried out by CNI among member companies, $70 \%$ of organizations are unaware of the terminology circular economy, but, at the same time, when asked about the existence of circular practices in companies, $76.4 \%$ affirm that they exist but they were not aware that such practices fit this concept (CNI, 2019). In addition, recent research in the literature indicates that most studies are related to the benefits and philosophy of Circular Economy, not exploring the main difficulties that can be observed to implement circular practices in its operations (KUMAR; SINGH; KUMAR, 2021).

\section{THEORETICAL FOUNDATION}

The main barriers to implement circular economy practices have been selected in the literature. In order to facilitate the organization and paired comparisons of specialists, the barriers were divided into the following categories: Financial and Economic (FE), Human Factors (HF), Technical Information (TI) and Operational and Strategic (OS).

Financial barriers are related to the lack of investments to adopt sustainable models and, in addition, the difficulty in measuring the financial benefits that the adoption of circular economy practices can generate in organizations (VAN BUREN et al. 2016; RITZÉN; SANDSTROM et al. 2017).

Human factors are preponderant for circular operations to be adopted in organizations, so there is a need for greater employee engagement, however, resistance to change is a major challenge when new practices can be adopted (JABBOUR; JABBOUR, 2016). The lack of 
awareness for adopting such practices and the lack of knowledge on the subject can be pointed out as the main difficulties related to human factors (RUGGIERI et al. 2016; AGYEMANG et al. 2018).

The lack of collaboration among all stakeholders, especially the links in the supply chains, also interfere in the execution of more sustainable models, as well as technological restrictions aimed at the implementation of practices. These specific barriers are categorized as technical information barriers (TINGLEY; COOPER; CULLEN, 2017; CNI, 2019).

Finally, there are also difficulties relating to operational and strategic barriers, such as, for example, the resistance of top management in relation to the topic and deeply-rooted operational standards (VAN BUREN et al. 2016; JABBOUR et al. 2018). Table 1 systematizes the barriers that were selected in the literature. The Table divides the barriers into categories, presents a description of each specific barrier and identifies the corresponding sources. These variables are considered as inputs for the hierarchical structuring of the problem.

Table 1. Barriers related to the implementation of Circular Economy practices

\begin{tabular}{|c|c|c|c|}
\hline Categories & Specific Barriers & Description & Source \\
\hline \multirow[t]{2}{*}{$\begin{array}{l}\text { Financial and } \\
\text { Economic }\end{array}$} & $\begin{array}{l}\text { Financial and Cost } \\
\text { constraints (FE1) }\end{array}$ & $\begin{array}{l}\text { The lack of capital investment } \\
\text { compromises the adoption of a more } \\
\text { sustainable model. }\end{array}$ & $\begin{array}{l}\text { ORMAZABAL et al. 2016; } \\
\text { SHAHBAZI et al. 2016; } \\
\text { VAN BUREN et al. 2016; } \\
\text { AID et al. 2017; } \\
\text { AGYEMANG et al. } 2018\end{array}$ \\
\hline & $\begin{array}{l}\text { Difficulty in measuring } \\
\text { the financial benefits of } \\
\text { the circular economy } \\
\text { (FE2) }\end{array}$ & $\begin{array}{l}\text { As this is a new model, there are } \\
\text { difficulties in measuring the benefits } \\
\text { that the circular economy will bring } \\
\text { financially over a period of time. }\end{array}$ & $\begin{array}{c}\text { RITZÉN \& SANDSTROM } \\
\text { et al. } 2017\end{array}$ \\
\hline
\end{tabular}

Lack of financial Lack of investment and government

TURA et al. 2019 incentive and support for the adoption of circular government support economy practices, making it difficult (FE3) for organizations to spread sustainable ideas.

\begin{tabular}{|c|c|c|}
\hline $\begin{array}{l}\text { Human } \\
\text { Factors }\end{array}$ & $\begin{array}{l}\text { Lack of interest on the } \\
\text { part of those involved } \\
\text { (HF1) }\end{array}$ & $\begin{array}{c}\text { When the organization's employees are } \\
\text { not interested in adopting a new, more } \\
\text { sustainable model, adoption becomes } \\
\text { more difficult. }\end{array}$ \\
\hline
\end{tabular}

VAN BUREN et al. 2016;

AID et al. 2017 more difficult. 
new circular model ends up impaired.

Lack of specialization Employees and stakeholders do not on $\mathrm{CE}$ (HF3) have adequate expertise to change

$\begin{array}{cc}\text { Technical } & \text { Lack of collaboration } \\ \text { Information } & \text { within the supply chain }\end{array}$

(TI1)

Lack of knowledge about terminology and main characteristics of the circular economy

(TI2)

Lack of technological capacity (TI3) business models and diagnose the benefits that circular economy practices can bring to organizations.
Lack of commitment from suppliers, customers and other links in the organization's supply chain to adopt and encourage sustainable practices.

The lack of knowledge about the activities that are related to the circular economy does not allow a survey and studies on how such practices are used in organizations, causing inconsistencies on the subject.
AGYEMANG et al. 2018

TINGLEY, COOPER \&

CULLEN 2017;

TODESCHINI et al. 2017

FIGUEIREDO, 2019; CNI, 2019

Lack of technical resources for the implementation of new business models based on circular economy practices

When a company has experienced years of other practices, for example

linear economy, it is difficult to change to a new model.

Resistance to change from top management (OE2)
AGYEMANG et al. 2018

VAN BUREN et al. 2016

AGYEMANG et al. 2018; JABBOUR et al. 2018
If there is resistance to change from the point of view of senior management in changing the corporate strategy, aiming at the adoption of circular economy practices, the implementation of a more sustainable business model will be compromised.

Source: The authors (2021).

\section{METHODOLOGICAL PROCEDURES}

The research developed can be classified as quantitative and exploratory. The AHP method is used to obtain priorities and to classify barriers that interfere with the adoption of circular economy practices in organizations. The research has a quantitative approach, as it is a mathematical method that seeks to model a decision analysis based on multiple conflicting and comparable variables. The methodological framework of the research can be seen in Figure 1 and the steps of the AHP method are described in the next section.

To understand the difficulties of implementing circular economy practices, the study and the AHP method were developed in two organizations from different segments: a 
company in the food segment that produces ice cream (Company A) and a metalworking company that manufactures aluminum billets (Company B), both companies are located in the interior of the state of São Paulo.

Based on recent studies, the adoption of circular economy practices in the food segment is a determining factor for research, where this sector is central to the topic of a sustainable supply chain. In addition, population growth, increased demand for food, the entire distribution system within this chain and the high volume of waste in the food segment justify conducting studies and the transition to more sustainable practices (JURGILEVICH et al., 2016; GIUDICE et al., 2020).

In relation to the metalworking company, the transition to the circular economy has been addressed and suggested in some areas, such as infrastructure and construction, and electrical and electronic equipment (EEE) (EMF, 2017). As such, metalworking companies, mainly those businesses that manufacture aluminum billets are part of the supply chain, that supply materials directly to the above-mentioned sectors. In addition, the growing demand for metal along with the depletion of metal resources are some of the most important environmental challenges today, as well as the management of this waste (SETHURAJA; GAYDARDZHIEV, 2021).

Employees who hold management / leadership positions and who are directly related to the adoption of circular economy practices were contacted to answer a questionnaire on the AHP method. Studies involving multicriteria analyzes do not require a large number of respondents in the analysis, since many questionnaires are not validated because due to inconsistent questions when comparing pairs (GOVINDAN et al., 2014; BELHADI; TOURIKI; EL FEZAZI, 2017). It is important for specialists to hold considerable influence on the analysis, that is, professionals who have the knowledge and autonomy for decisionmaking. Recent studies demonstrate the application of multicriteria analyzes based on the opinions of a few experts, but influence decision-making (LAMBA et al., 2019; TALAPRATA; UDDIN, 2019; KUMAR). Also note the prescriptive focus of the AHP method carried out in this study, that is, the description of all the elements that surround the decision making were previously raised in the literature (GOMES, 2007). Specific barriers were categorized and subsequently applied by specialists, as shown in stage 2 of Figure 1.

Studies that apply multicriteria methodology basically use questionnaires to collect data. This questionnaire is based on paired comparisons that will determine the weights for 
each selected criterion, and thus, point out the main barriers for adopting circular economy practices in the operating procedures of the organizations. After collecting data, through questionnaires, the answers given by the specialists were analyzed, applying essential mathematical tools in the AHP method. Mainly, the weighting of criteria by the specialists, the analysis of the consistency of the answers and the classifications of barriers for both companies taking part in the study were analyzed. The next section shows how the AHP methodology was structured, as well as a detailed description of the stages.

Figure 1. Research Methodological Framework

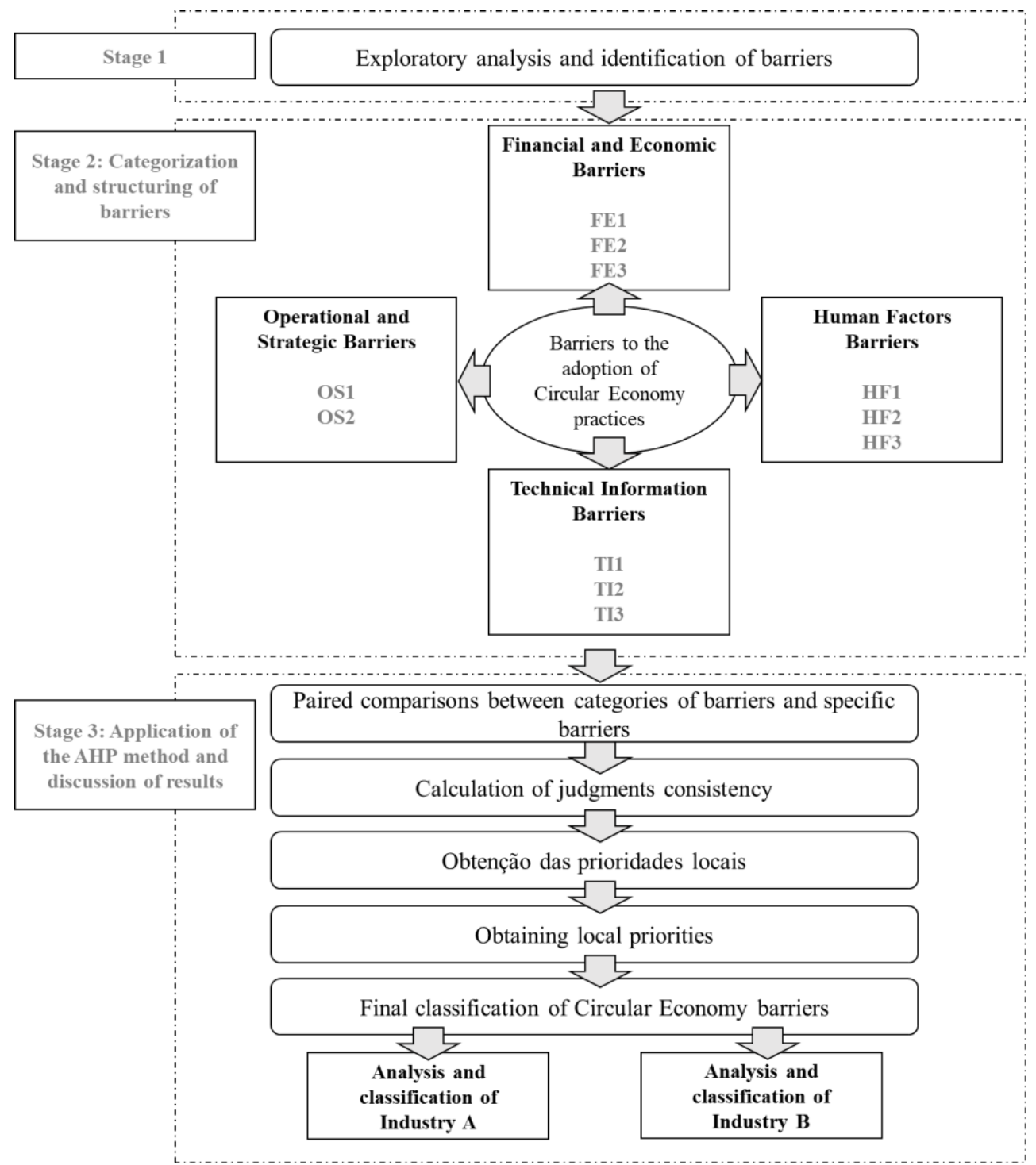

Source: The authors (2021). 


\subsection{Methodological procedures of the AHP method}

\section{Step 1: Survey of variables and formulation of the AHP structure}

To structure the problem, an exploratory analysis in the literature was carried out, identifying the barriers that interfere in the adoption of circular economy practices. The barriers were divided into four categories: technical information barriers, economic and financial barriers, human factor barriers and operational and strategic barriers. Figure 2 shows the hierarchical structure of the AHP method.

The levels of the hierarchy were determined as follows:

Level 1: General objective of the research;

Level 2: Categories of barriers;

Level 3: Specific barriers according to each category;

Level 4: Classification of the main barriers in the adoption of circular economy practices.

Figure 2. Hierarchical structuring of the problem

Level 1

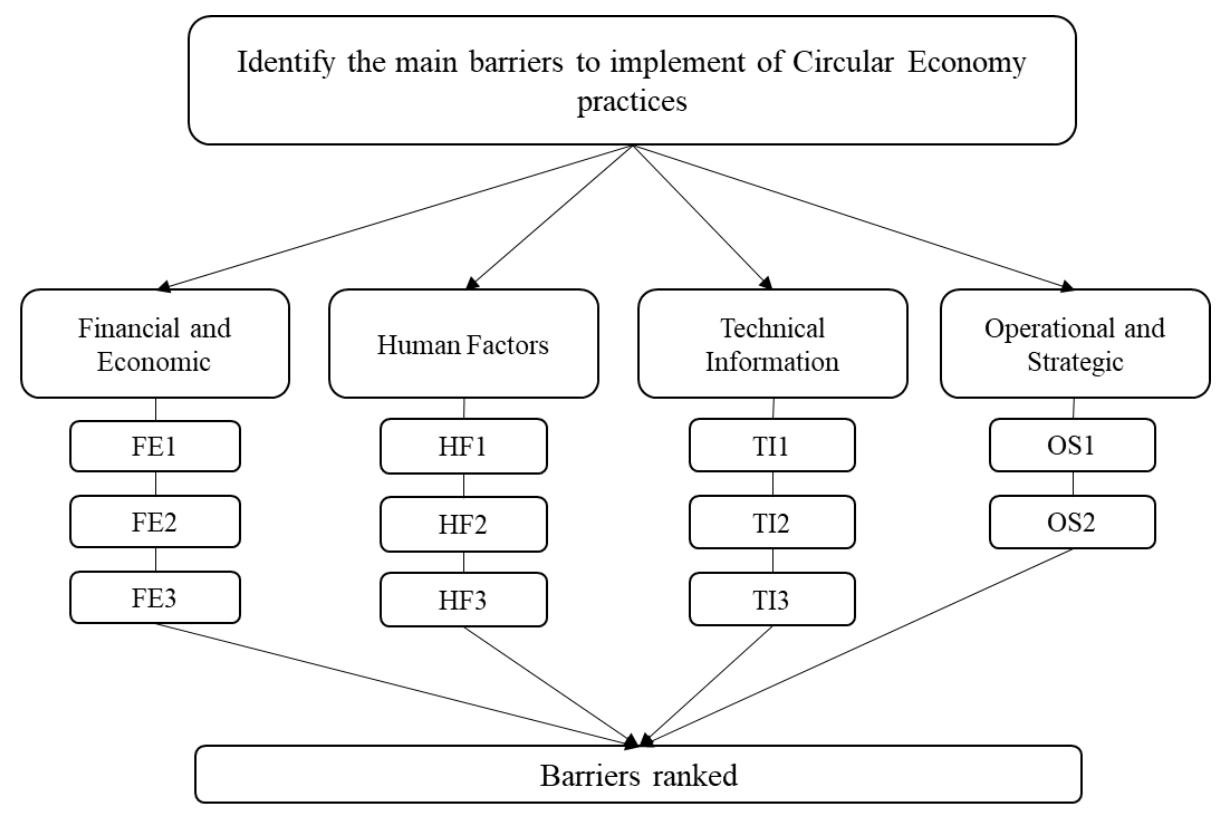

Source: The authors (2021).

Step 2: paired comparisons and calculating the consistency of responses.

After defining and structuring the problem hierarchy, paired comparisons were made using the AHP questionnaire. The AHP method only shows relationships between the levels 
of the hierarchy, with that, a questionnaire was developed respecting these relationships. Paired comparisons were judged according to the Saaty scale (1990), as shown in Table 2:

Table 2. Saaty's fundamental scale

\begin{tabular}{|c|c|c|}
\hline $\begin{array}{l}\text { Intensity of } \\
\text { importance }\end{array}$ & Definition & Explanation \\
\hline 1 & Equal importance & Two activities contribute equally to the goal. \\
\hline 3 & Moderate & $\begin{array}{l}\text { Experience and judgment slightly favor one activity } \\
\text { over another. }\end{array}$ \\
\hline 5 & Strong & $\begin{array}{l}\text { Experience and judgment strongly favor } \\
\text { one activity over another. }\end{array}$ \\
\hline 7 & Very strong & $\begin{array}{l}\text { One activity is favored very strongly over another and } \\
\text { its dominance is demonstrated in practice. }\end{array}$ \\
\hline 9 & Extreme & $\begin{array}{l}\text { The evidence favoring one activity over another is of } \\
\text { the highest possible order of affirmation. }\end{array}$ \\
\hline $2,4,6,8$ & Intermediate values & $\begin{array}{l}\text { Used to represent a compromise between the } \\
\text { preferences listed above. }\end{array}$ \\
\hline Reciprocity & $\begin{array}{l}\text { If activity i is assigne } \\
\text { activity } j, \text { th }\end{array}$ & $\begin{array}{l}\text { one of the above non-zero numbers when compared to } \\
\mathrm{j} \text { has a reciprocal value when compared to } \mathrm{i}\end{array}$ \\
\hline
\end{tabular}

Source: Saaty (1990).

One of the characteristics of the AHP method is the possibility of checking the consistency of the responses. The consistency ratio can be calculated according to the equations shown below:

$$
\begin{gathered}
\mathrm{IC}=(\lambda \max -n) / n-1 \\
\mathrm{CR}=\mathrm{IC} / \mathrm{RI}
\end{gathered}
$$

Where: $\lambda \max$ is the eigenvalue of each decision matrix, $\mathrm{n}$ establishes the matrix order and IR is the random index according to the number of criteria in each matrix (SAATY, 1990). The values of RI (Random Index) are shown below, according to the matrix order ( $n$ ).

Table 3. Random Index

\begin{tabular}{ccccccccccc}
\hline $\boldsymbol{n}$ & 1 & 2 & 3 & 4 & 5 & 6 & 7 & 8 & 9 & 10 \\
\hline Random Index & 0 & 0 & .52 & .89 & 1.11 & 1.25 & 1.35 & 1.40 & 1.45 & 1.49
\end{tabular}

Source: Saaty (1990). 


\section{Step 3: Aggregation of priorities and analysis of results}

The aggregation of priorities using the AHP method is carried out by multiplying the weights between the levels of the hierarchy. Firstly, the weights of the barrier categories are established. In a second step, the weights of the specific barriers for each category are calculated, these weights are called local weights. Subsequently, global weights are obtained by multiplying the weights of each category by the local weights.

After determining the global weights, a final classification of the barriers is obtained. In this study, two classifications were defined: food company (Company A) and metalworking company (Company B). The results of both classifications were compared in order to identify the differences, perceptions and analyzes of the barriers that most interfere in the adoption of circular economy practices, considering the specificities of each organization participating in the study. In addition, the sensitivity analysis, a procedure used to test the stability of the final ranking of priorities, was conducted for one of the companies.

Only one classification was used to perform the sensitivity analysis due to the significant differences in the weights of the barrier categories for one of the companies that took part in the decision analysis process.

\section{RESULTS}

The mathematical procedures in the AHP method were used to establish the weights for barrier categories and specific barriers. Analyzes were carried out in both organizations. After carrying out the mathematical procedures and testing the consistency of the matrices, weights for barrier categories and specific barriers were found, as well as the classification of barriers for both companies.

After the questionnaire had been given to company expert A, mathematical procedures were carried out. It is important to note that all calculated decision matrices were considered consistent, validating the answers for the analysis according to the methodological proposal in the AHP.

Weights of the barrier categories, the specific barriers and the classifications of companies A and B can be seen in Tables 4 and 5: 
Table 4. Classification of Company A barriers

\begin{tabular}{cccccc}
\hline Barriers Category & Weights & Specific Barriers & Weights & $\begin{array}{c}\text { Global } \\
\text { Weights }\end{array}$ & Ranking \\
\hline Financial and Economic & 0.2481 & FE1 & 0.6000 & 0.1489 & 2 \\
& & FE2 & 0.2000 & 0.0496 & 7 \\
Human Factors & \multirow{2}{*}{0.2087} & FE3 & 0.2000 & 0.0496 & 7 \\
& & HF1 & 0.4742 & 0.0989 & 4 \\
Technical Information & \multirow{2}{*}{0.2951} & HF2 & 0.3764 & 0.0785 & 5 \\
& & HF3 & 0.1494 & 0.0312 & 8 \\
Operational and Strategic & \multirow{2}{*}{0.2481} & TI2 & 0.4000 & 0.1180 & 3 \\
& & TI3 & 0.2000 & 0.0590 & 6 \\
& & OE1 & 0.1000 & 0.1180 & 3 \\
& & OE2 & 0.8750 & 0.0310 & 9 \\
\hline
\end{tabular}

Source: The authors (2021).

Table 5. Classification of Company B barriers

\begin{tabular}{cccccc}
\hline Barriers Category & Weights & Specific Barriers & Weights & $\begin{array}{c}\text { Global } \\
\text { Weights }\end{array}$ & Ranking \\
\hline Financial and Economic & 0.6830 & FE1 & 0.2790 & 0.1905 & 2 \\
& & FE2 & 0.0719 & 0.0491 & 5 \\
Human Factors & \multirow{2}{*}{0.0563} & FE3 & 0.6491 & $\mathbf{0 . 4 4 3 3}$ & $\mathbf{1}$ \\
& & HF1 & 0.0719 & 0.0041 & 11 \\
\multirow{2}{*}{ Technical Information } & \multirow{2}{*}{0.1527} & HF2 & 0.2790 & 0.0157 & 8 \\
& & HF3 & 0.6491 & 0.0366 & 7 \\
Operational and Strategic & \multirow{2}{*}{0.1080} & TI1 & 0.0719 & 0.0110 & 9 \\
& & TI2 & 0.6491 & 0.0991 & 3 \\
& & TI3 & 0.2790 & 0.0426 & 6 \\
& & OE1 & 0.1000 & 0.0108 & 10 \\
\hline
\end{tabular}

Source: The authors (2021).

Note that Resistance to change by top management (OS2), Financial and cost constraints (FE1), Lack of technical and technological capacity (TI3) and Lack of collaboration across the supply chain (TI1) were identified as the barriers most relevant to the adoption of CE practices in Company A.

The main barrier was resistance to change from top management, demonstrating that a lack of support is fundamental to the failure to apply more sustainable ideas. The leaders of the organizations are responsible for changing the attitude of all employees and processes, but without this support, the adoption of these practices is completely unfeasible. When studies with a sustainable bias are performed, resistance to change from top management presents significant weights in the analysis (MANGLA; GOVINDAN; LUTHRA, 2017). Financial and 
cost restrictions of an organization is also a fundamental factor for the unfeasibility in adopting circular economy practices.

Tingley, Cooper and Cullen (2017) pointed out that circular economy practices must be adopted throughout the supply chain, that is, changing the attitude of just one link in the chain is not enough, everyone must be involved in the implementation process. The results of Company A confirm what has been pointed out by the aforementioned authors. The adoption of circular practices in organizations in the food sector tend to simultaneously increase the sustainability of the value chain and improve the resilience of supply chains, minimizing waste and driving sustainable decisions in relation to production and consumption (GIUDICE; CAFERRA; MORONE, 2020). The alignment between production, consumption and waste must be a fundamental practice for companies in the food sector in an attempt to overcome the TI3 and Ti1 barriers, highlighted above.

The same procedure was applied to Company B. For Company B, a review of the judgments was necessary, ensuring the consistency of specialist responses. Note that the weight attributed to financial and economic barriers was quite different from the other categories. This weight was decisive for the final classification of barriers, in which a lack of financial incentive and government support (FE3) and the restriction of capital and costs (FE1) were the main barriers. A lack of knowledge on circular economy practices (TI2) makes up the three main barriers in the view of Company B. A lack of knowledge of these practices does not allow those involved to understand the benefits of $\mathrm{CE}$.

Incentives and investments are essential for the dissemination of such practices. These are the most significant difficulties from the point of view of Company B. There is a need for greater confidence in the circular economy business processes and models. When there is no adequate support from investment sources, mainly small and medium-sized enterprises, they tend to decrease their chances of adopting these practices and not realizing the potential of using circular models (FAROOQUE; ZHANG; LIU, 2019; SOUZA, 2021).

When results from Companies A and B are compared, it is found that, for Company A, the most relevant factor in relation to the adoption of new sustainable practices in the production process is directly related to the lack of support and engagement from senior management in carrying out sustainable practices, in Company $\mathrm{B}$, the main factor linked to the new practices is mainly related to the financial and economic factor, capital investment, in 
contrast, both companies have technical information factors as obstacles to adopt new sustainable practices.

The results demonstrate that there are significant differences in the weights of the barrier categories between both companies. In Company A, the main difficulties identified are related to issues of Technical Information, while in Company B the Financial and Economic category was identified as the most prevalent barrier when related to Circular Economy practices, with a significantly greater weight in relation to the other categories. Such differences between the weights of the barrier categories in both companies allow a sensitivity analysis of the results to be adopted.

A sensitivity analysis is considered to be the last step of the AHP methodological procedure and is used to test the final ranking of the priorities for alternatives in a decisionmaking process. The weights of the barrier categories directly influence the final ranking of specific barriers, so different scenarios can be obtained by increasing or decreasing the weights of the barrier categories which had the greatest impact according to the judgments of the experts (CHANG et al., 2007; ISHIZAKA; LABIB, 2011). The sensitivity analysis, in this study, was only performed for Company B, as the results obtained demonstrate a very significant difference between the barrier categories. To carry out a sensitivity analysis, the variant element is the weight of the barrier category "Financial and Economic", that is, when this weight varies, how does it impact the final ranking of the barriers? The weight of the criterion varied from 0.1 to 0.9 and the impact on the final classification of barriers for Company B can be seen in Table 6 .

Table 6. Impact of the variation in the weight of the "Financial and Economic" category on specific barriers

\begin{tabular}{cccccccccccc}
\hline Peso & FE1 & FE2 & FE3 & HF1 & HF2 & HF3 & TI1 & TI2 & TI3 & OS1 & OS2 \\
\hline $\mathbf{0 . 0 0 0 0}$ & 0.0000 & 0.0000 & 0.0000 & 0.0842 & 0.0668 & 0.0265 & 0.1927 & 0.0963 & 0.1927 & 0.0426 & $\mathbf{0 . 2 9 8 1}$ \\
$\mathbf{0 . 1 0 0 0}$ & 0.0600 & 0.0200 & 0.0200 & 0.0758 & 0.0602 & 0.0239 & 0.1734 & 0.0867 & 0.1734 & 0.0383 & $\mathbf{0 . 2 6 8 3}$ \\
$\mathbf{0 . 2 0 0 0}$ & 0.1200 & 0.0400 & 0.0400 & 0.0674 & 0.0535 & 0.0212 & 0.1541 & 0.0771 & 0.1541 & 0.0341 & $\mathbf{0 . 2 3 8 5}$ \\
$\mathbf{0 . 3 0 0 0}$ & 0.1800 & 0.0600 & 0.0600 & 0.0590 & 0.0468 & 0.0186 & 0.1349 & 0.0674 & 0.1349 & 0.0298 & $\mathbf{0 . 2 0 8 7}$ \\
$\mathbf{0 . 4 0 0 0}$ & $\mathbf{0 . 2 4 0 0}$ & 0.0800 & 0.0800 & 0.0505 & 0.0401 & 0.0159 & 0.1156 & 0.0578 & 0.1156 & 0.0256 & 0.1789 \\
$\mathbf{0 . 5 0 0 0}$ & $\mathbf{0 . 3 0 0 0}$ & 0.1000 & 0.1000 & 0.0421 & 0.0334 & 0.0133 & 0.0963 & 0.0482 & 0.0963 & 0.0213 & 0.1491 \\
$\mathbf{0 . 6 0 0 0}$ & $\mathbf{0 . 3 0 0 0}$ & 0.1000 & 0.1000 & 0.0421 & 0.0334 & 0.0133 & 0.0963 & 0.0482 & 0.0963 & 0.0213 & 0.1491 \\
$\mathbf{0 . 7 0 0 0}$ & $\mathbf{0 . 4 2 0 0}$ & 0.1400 & 0.1400 & 0.0253 & 0.0201 & 0.0080 & 0.0578 & 0.0289 & 0.0578 & 0.0128 & 0.0894 \\
$\mathbf{0 . 8 0 0 0}$ & $\mathbf{0 . 4 8 0 0}$ & 0.1600 & 0.1600 & 0.0168 & 0.0134 & 0.0053 & 0.0385 & 0.0193 & 0.0385 & 0.0085 & 0.0596
\end{tabular}


\begin{tabular}{llllllllllll}
$\mathbf{0 . 9 0 0 0}$ & $\mathbf{0 . 5 4 0 0}$ & 0.1800 & 0.1800 & 0.0084 & 0.0067 & 0.0027 & 0.0193 & 0.0096 & 0.0193 & 0.0043 & 0.0298 \\
\hline
\end{tabular}

Source: The authors (2021).

Figure 3 presents, graphically, the impact of the variability of the weights of the "Financial and Economic" barrier category on the weights of specific barriers. Analyzing the table and graph, it can be induced that when the weight of the "Financial and Economic" category varies between 0 and 0.3 , the barrier to resistance to change by senior management (OS2) is the priority. As from a weight of 0.4 , the priority barrier is financial and cost restrictions (FE1). These results demonstrate that it is extremely significant for Company 2 to seek improvements to overcome financial and economic barriers that prevent the adoption of circular economy practices. With the elimination of these barriers alone, the results could show significant improvements. The sensitivity analysis contributes to showing greater robustness in a multicriteria analysis and to present other directions according to the results found.

Figure 3. Graphical analysis of the weights of specific barriers with the variation of the weight of the "Financial and Economic" category

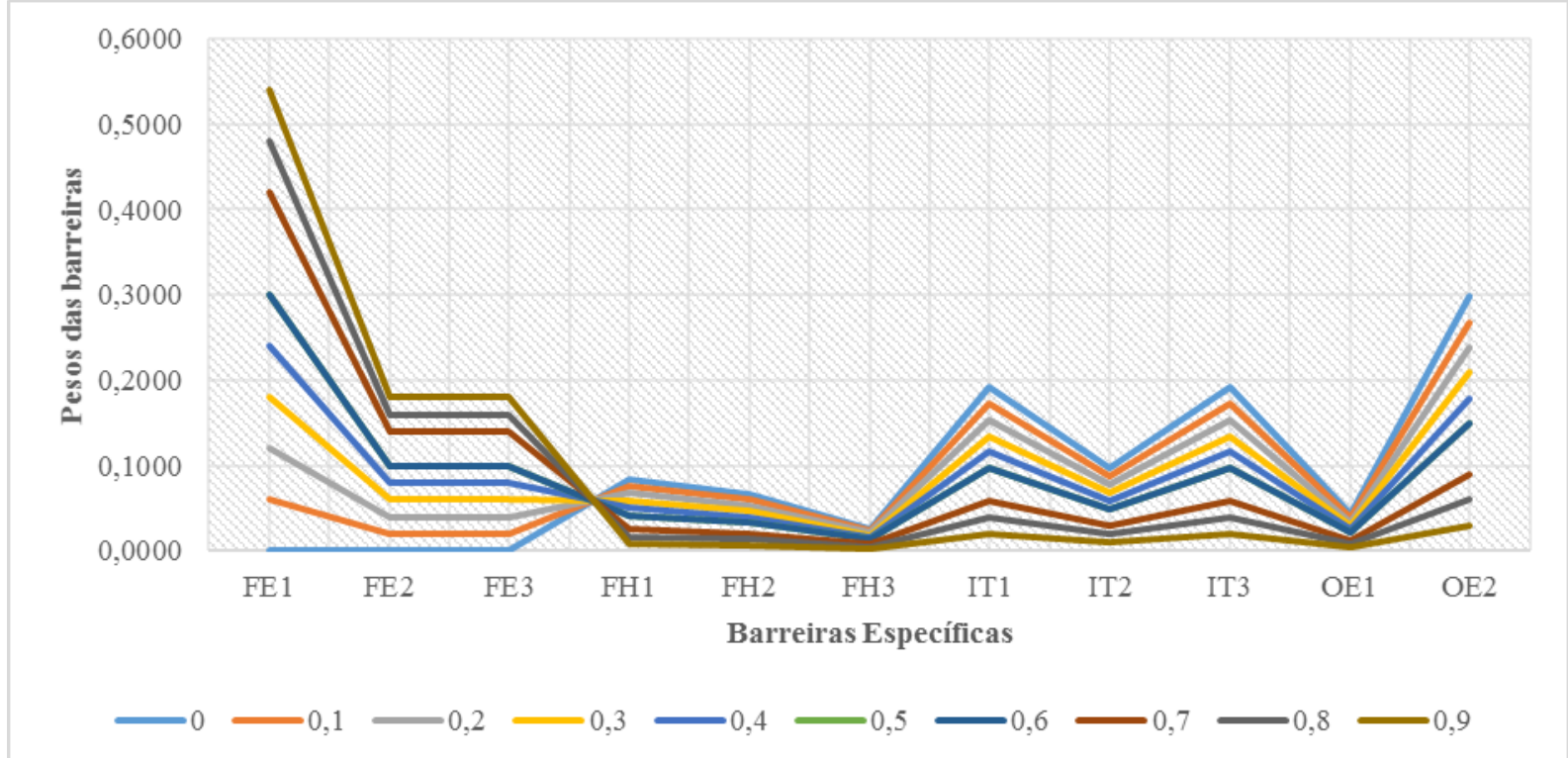

Source: The authors (2021). 


\section{CONCLUSION}

This study aimed to classify the main barriers to adopt circular economy practices in companies, using the Analytic Hierarchy Process (AHP) method. The study was carried out in two companies in the food and metalworking segments, where a questionnaire with paired comparisons was developed and given to measure the degree of importance according to each of the specialists. The questionnaires were given and the mathematical procedures from the AHP were used to obtain the barrier priorities.

The study suggests that the main barrier, from the point of view of a company in the food sector, is resistance to change by top management, while the metalworking company points to a lack of financial incentive and government support as the barrier that most interferes in the adoption of circular practices in the organization's business models. Another result is that the companies differ in relation to the weights of the barrier categories. Company A points to the barriers of Technical Information as having more of an impact in the analysis and Company B shows a very significant weight for the category of financial and economic barriers.

Considering the contributions from a theoretical perspective, the study contributes empirically in demonstrating which barriers mostly impact the adoption of circular economy practices in the business models of the organizations studied and also contributes to an understanding of the perceptions found in both companies, which are different segments on this relevant topic in the recent literature. Another important contribution is that the study can guide decision makers and managers in understanding the difficulties encountered and how the management of organizations can use their efforts to adopt these practices. Future studies can be conducted for different companies and stakeholders for comparison purposes, using multicriteria methodologies and also using potential alternatives in the methodological framework to overcome these barriers.

This study allows information to be collected regarding the difficulties that exist in the adoption of circular economy practices. The article has some limitations regarding the applicability and generalization of the results since they are from specific situations. Studies with a larger number of participants, from more varied segments, can be conducted and compared with the findings of this study. Since this is a new topic in the literature, the variables (barriers) selected in the analysis are not limited to those used in the methodological 
scope of the study, therefore, new research into these barriers along with updates can be included in future proposals on methodology, as well as the establishment of relationships between barriers using other multicriteria techniques, such as, for example, the use of methods that allow the relationship between barriers to be verified, regardless of hierarchical levels.

The study demonstrated the ease of application and interpretation of the AHP method in research aimed at prioritizing barriers. Since it is a method that does not require methodological and computational approaches that are difficult to understand, the relevance of the methodology in decision-making processes in organizations is noted, in addition to highlighting possible cases of inconsistencies in the replies from the specialists selected for analysis. In addition, recent studies in the literature point out that the most important consideration in applying the methodology is the selection of trained professionals with decision-making autonomy and that a few professionals can be selected to carry out paired comparisons of the method. Future approaches using decision-making groups with greater interactivity between the facilitator and the experts, using integrated methodologies, can be adopted.

Other opportunities can also be explored involving the multicriteria technique and circular economy practices, such as studies that address the main drivers for adopting circular economy practices and also studies that link circular economy practices with new business models of organizations. Based on the results obtained, the study can provide insights for managers in food and metalworking companies, in order to find solutions, strategies or plans to overcome barriers.

\section{References}

AGYEMANG, M.; KUSI-SARPONG, S.; KHAN, S.A.; MANI, V.; REHMAN, S.T.; KUSISARPONG, H. Drivers and barriers to circular economy implementation: an explorative study in Pakistan's automobile industry. Management Decision, v. 57, n. 4, p. 971-994, 2019.

ARAYA-PIZARRO, S. C.; ARAYA-PIZARRO, C. R. Priorización Multicriterio de Mercados Potenciales de Comercio Justo. Inf. tecnol., v. 30, n. 5, p. 309-318, oct. 2019 . Disponivel em: https://scielo.conicyt.cl/scielo.php?script=sci_arttext\&pid=S07180764201900050030 9\&lng=es\&nrm=iso. Acesso em: 16 Jul. 2020. 
BELHADI, A. Prioritizing the solutions of lean implementation in SMEs to overcome its barriers. Journal of Manufacturing Technology Management, v. 28, n. 8, p. 1115-1139, 2017. https://doi.org/10.1108/JMTM-04-2017-0066.

BHANDARI, D., RAJESH K. R.; GARG, S. K. Prioritisation and evaluation of barriers intensity for implementation of cleaner technologies: Framework for sustainable production. Resources, Conservation \& Recycling, n. 146, p. 156-167, 2019.

BUREN, N. V.; DEMMERS, M.; HEIJDEN, R. V.; WITLOX, F. Towards a circular economy: The role of Dutch logistics industries and governments. Sustainability, Multidisciplinary Digital Publishing Institute, v. 8, n. 7, p. 647, 2016.

CHANG, C. W.; WU, C. R.; LIN, C. T. An application of AHP and sensitivity analysis for selecting the best slicing machine. Computers \& Industrial Engineering, v. 52, p. 296-307, 2007.

CNI (CONFEDERAÇÃO NACIONAL DA INDÚSTRIA). Pesquisa sobre Economia Circular - 2019. Ano 1, n. 1, Abril de 2020. Disponível em: http://www.portaldaindustria.com.br/cni/canais/industria-sustentavel/temas-de atuacao/economia-circular/. Acesso em: 04 Mai. 2020.

DALFOVO, M. S.; LANA, R. A.; SILVEIRA, A. Métodos quantitativos e qualitativos: um resgate teórico. Revista Interdisciplinar Científica Aplicada, Blumenau, v.2, n.4, p.01-13, 2008.

GERHARDT, T. E.; SILVEIRA, D. T. (organizadores). Métodos de Pesquisa. Coordenado pela Universidade Aberta do Brasil - UAB/UFRGS e SEAD/UFRGS. Porto Alegre: Editora da UFRGS, 2009.

GIUDICE, F.; CAFERRA, R.; MORONE, P. COVID-19, the Food System and the Circular Economy: Challenges and Opportunities. Sustainability, v. 12, 2020.

GOMES, L. F. A. M. Teoria da decisão. São Paulo: Thomson, 2007.

GOVINDAN, K. et al. Production Economics Barriers analysis for green supply chain management implementation in Indian industries using analytic hierarchy process. Intern. Journal of Production Economics, v. 147, p. 555-568, 2014.

GRAFSTROM, J.; AASMA, S. Breaking circular economy barriers. Journal of Cleaner Production, v. 292, 202. https://doi.org/10.1016/j.jclepro.2021.126002

HARPUTLUGIL, T.; PRINS, M.; GULTEKIN, T.; TOPCU, I. Conceptual framework for potential implementations of multi criteria decision making (MCDM) methods for design quality assessment. In: MANAGEMENT AND INNOVATION FOR A SUSTAINABLE BUILT ENVIRONMENT. Anais...Amsterdam, The Netherlands, June 20-23, 2011. ISBN:9789052693958. 
ISHIZAKA, A. LABIB, A. Review of the main developments in the analytic hierarchy process. Expert Systems with Applications, v. 38, p. 14336-14345, 2011.

JABBOUR, C.J.C., JABBOUR, A.B.L.S. Green human resource management and green supply chain management: linking two emerging agendas. Journal of Cleaner Production, v. 112, p. 1824-1833, 2016.

JABBOUR, C.J.C.; JABBOUR, A.B.L.S.; SARKIS, J.; GODINHO FILHO, M. Unlocking the circular economy through new business models based on large-scale data: an integrative framework and research agenda. Technological Forecasting and Social Change, v. 144, p. 546-552, 2019.

JURGILEVICH, A.; BIRGE, T.; KENTALA-LEHTONEN, J.; KORHONEN-KURKI, K.; PIETIKÄINEN, J.; SAIKKU, L.; SCHÖSLER, H. Transition towards Circular Economy in the Food System. Sustainability, v. 8, n. 1, 2016. https://doi.org/10.3390/su8010069

KIRCHHERR, J.; REIKE, D.; HEKKERT, M. Conceptualizing the circular economy: An analysis of 114 definitions. Resources, Conservation and Recycling, Elsevier, v. 127, p. 221-232, 2017.

KUMAR, S.; GOVINDAN, K.; LUTHRA, S. Prioritizing the barriers to achieve sustainable consumption and production trends in supply chains using fuzzy Analytical Hierarchy Process. Journal of Cleaner Production, v. 151, p. 509-525, 2017.

LAMBA, D.; YADAV, D. K.; BARVE, A.; PANDA, G. Prioritizing barriers in reverse logistics of E-commerce supply chain using fuzzy-analytic hierarchy process. Electronic Commerce Research, v. 20, n. 381-403, 2020.

LEITÃO, A. Economia circular: uma nova filosofia de gestão para o séc. XXI. Portuguese Journal of Finance, Management and Accounting, v. 1, n. 2, p. 149-171, 2015.

LIEDER, M.; RASHID, A. Towards circular economy implementation: a comprehensive review in context of manufacturing industry. Journal of Cleaner Production, v, 115, p. 3651, 2016. http://dx.doi.org/10.1016/i.jclepro.2015.12.042

MANGLA, S. K.; GOVINDAN, K.; LUTHRA, S. Prioritizing the barriers to achieve sustainable consumption and production trends in supply chains using fuzzy Analytical Hierarchy Process. Journal of Cleaner Production, v. 151, p. 509-525, 2017.

MARCHEZETTI, A. L.; KAVISKI, E.; BRAGA, M. C. B. Aplicação do método AHP para a hierarquização das alternativas de tratamento de resíduos sólidos domiciliares. Ambient. constr. (Online), Porto Alegre, v. 11, n. 2, p. 173-187, 2011.

MATHEWS, J. A.; TAN, H. Progress toward a circular economy in China. Journal of industrial ecology. Wiley Online Library, v. 15, n. 3, p. 435-457, 2011. 
ONU (Organização das Nações Unidas). Objetivos de desenvolvimento sustentável - A agenda 2030 para o desenvolvimento sustentável. 49 p. 2015 . Acesso em: 08 jun. 2020.

PRAKASH, C.; BARUA, M. K. A Multi-criteria Decision-making Approach for Prioritizing Reverse Logistics Adoption Barriers under Fuzzy Environment: Case of Indian Electronics Industry. Global Business Review, v. 17, n. 5, p. 1107-1124, 2016. https://doi.org/10.1177/0972150916656667.

RITZEN, S.; SANDSTROM, G.O. Barriers to the Circular Economy-integration of perspectives and domains. Procedia CIRP, v. 64, p. 7-12, 2020.

RIZOS, V.; BEHRENS, A.; GAAST, W. Van der; HOFMAN, E.; IOANNOU, A.; KAFYEKE, T.; FLAMOS, A.; RINALDI, R.; PAPADELIS, S.; HIRSCHNITZ-GARBERS, M.; TOPI, C. Implementation of circular economy business models by small and mediumsized enterprises (SMES): Barriers and enablers. Sustainability, Multidisciplinary Digital Publishing Institute, v. 8, n. 11, p. 1212, 2016.

SAATY, T. L. How to make a decision: The analytic hierarchy process. European Journal of Operational Research, v. 48, p. 9-26, 1990.

SETHURAJAN, M.; GAYDARDZHIEV, S. Bioprocessing of spent lithium ion batteries for critical metals recovery - A review. Resources, Conservation and Recycling, v. 165, 2021. https://doi.org/10.1016/i.resconrec.2020.105225.

SINTRA, P. V. Jornada técnica SOBRE ECONOMIA CIRCULAR. Smart Waste Portugal, $2019 . \quad$ Disponível em: $<$ http://m.smartwasteportugal.com/fotos/editor2/jornada_economia_circular_programa_provis orio.pdf>. Acesso em: 17 abr. 2020.

TALAPATRA, S; UDDIN, M. K. Prioritizing the barriers of TQM implementation from the perspective of garment sector in developing countries. Benchmarking an international journal, v. 26, n. 7, p. 2205-2224, 2019. https://doi.org/10.1108/BIJ-01-2019-0023.

TINGLEY, D. D.; COOPER, S.; CULLEN, J. Understanding and overcoming the barriers to structural steel reuse, a UK perspective. Journal of Cleaner Production, v. 148, p. 642-652, 2017.

WESTBLOM, C. Towards a Circular Economy in Sweden - Barriers for new business models and the need for policy intervention.2015. 195f. Dissertaçăo (Mestrado) International Institute for Industrial Environmental Economics (IIIEE), 2015. 